http://dx.doi.org/10.18778/7969-144-9.07

MAGDALENA DĄBROWSKA*

\title{
Problematyka pedagogiczna w kręgu zainteresowań wydawców rosyjskich przełomu XVIII i XIX wieku („okres nowikowowski” - „okres karamzinowski”)
}

Nikołaj Karamzin (1766-1826), poeta, prozaik, tłumacz, reformator rosyjskiego języka literackiego, historyk, wydawca almanachów i czasopism, poświęcił Nikołajowi Nowikowowi (1744-1818), publicyście, wydawcy gazet i czasopism, organizatorowi rynku wydawniczego i księgarskiego, osobny szkic Zapiska o N. I. Nowikowie (1818), a także szeroko wypowiedział się o nim w artykule O sprzedaży książek i miłości do czytania w Rosji (1802). W obu pracach wyeksponował wkład Nowikowa właśnie w rozpowszechnianie w państwie rosyjskim słowa drukowanego i kultury czytelniczej. „Pan Nowikow był w Moskwie głównym propagatorem sprzedaży książek" - pisał Karamzin w drugiej z nich, jako dowód podając następujące liczby: „dwadzieścia pięć lat temu były w Moskwie dwa sklepiki z książkami, które w ciągu roku nie sprzedawały ich nawet za dziesięć tysięcy rubli; teraz jest ich dwadzieścia i wszystkie razem zarabiają w roku ok. dwustu tysięcy rubli”" Zasługi Nowikowa na tym się jednak nie kończą: „Wynająwszy drukarnię uniwersytecką, zwiększył jej potencjał techniczny do drukowania książek, zlecał tłumaczenia, zakładał sklepiki z książkami w innych miastach, wszelkimi sposobami starał się zachęcić społeczeństwo do czytelnictwa. [...] Sprzedawał książki niczym bogaty kupiec holenderski czy angielski sprzedaje towary z całego świata [...]. Wcześniej gazety moskiewskie rozchodziły się w nakładzie nie więcej niż sześciuset egzemplarzy: p. Nowikow wzbogacił ich zawartość [...], wydawał wreszcie [...] bezpłatnie [czasopismo - M. D.] «Детское чтение», które

* Dr hab., prof. UW, Uniwersytet Warszawski, Wydział Lingwistyki Stosowanej, Instytut Rusycystyki, Zakład Historii Literatury Rosyjskiej, 02-678 Warszawa, ul. Szturmowa 4.

1 Н. М. Карамзин, О книжной торговле и любви ко чтению в России, [w:] tenże, Записки старого московского жителя. Избранная проза, Москва 1988, s. 322 (tu i dalej przekład własny - M. D.). 
spodobało się czytelnikom ze względu na [...] różnorodność problematyki. Liczba prenumeratorów z roku na rok rosła i w ciągu dziesięciu lat osiągnęła 4000..."2. W ocenie Karamzina, nie jest to wciąż stan zadowalający, ale bez kroku wykonanego przez Nowikowa Rosja jeszcze bardziej odstawałaby od reszty Europy.

„Okres nowikowowski” w dziejach rosyjskiego rynku wydawniczego - czy też, według określenia Wasilija Kluczewskiego, „nowikowowskie dziesięciolecie”3 - obejmuje lata 1779-1789. Rozpoczyna go przejęcie przez Nowikowa drukarni przy Uniwersytecie Moskiewskim, zamyka zaś wydawanie wspomnianego przez Karamzina czasopisma „Детское чтение для сердца и разума”; należy pamiętać jednak, że działalność Nowikowa na omawianym polu rozpoczęła się już pod koniec lat sześćdziesiątych XVIII wieku, gdy przystąpił do wydawania czasopism satyrycznych („Трутень” 1769-1770, „Пустомеля” 1770, „Живописец” 1772-1773, „Кошелек” 1774), a w 1773 roku założył wraz z księgarzem K. Millerem Towarzystwo Starające się o Drukowanie Książek, zakończyła się zaś w roku 1792, z chwilą aresztowania i uwięzienia w twierdzy Szlisselburskiej. W ciągu tych lat Nowikow zapisał się oprócz tego jako założyciel w 1784 roku Kompanii Typograficznej, zajmującej się nie tylko drukiem, ale i kolportażem książek, a także wydawca wielu - zróżnicowanych tematycznie i skierowanych do rozmaitych grup odbiorców - gazet i czasopism, poczynając od mistycznych czasopism masońskich (np. „Утренний свет” 1777-1780, razem z M. Chieraskowem), przez gazetę „Московские ведомости” (1779-1789) z dodatkiem literackim „Городская и деревенская библиотека" (1782-1786), a skończywszy na pismach dla kobiet („Модное Ежемесячное Издание, или Библиотека для дамского туалета” 1779), przy czym są to tylko przykłady ${ }^{4}$. Jeśli więc włączyć do „okresu nowikowowskiego" także lata 1768-1779 i 1789-792, można przyjąć za W. Siemiennikowem, że składa się on z dwóch podokresów: „petersburskiego”, obejmującego okres od roku 1766 do kwietnia 1779, oraz "moskiewskiego", trwającego od maja 1779 do kwietnia 1792 roku $^{5}$. Czasopismo „Детское чтение для сердца и разума” (1785-1789), pomyślane jako jeszcze jeden dodatek do gazety „Московские ведомости" i stanowiące - obok rozprawy O wychowaniu i nauczaniu dzieci (1783) - jeden z najbardziej wyrazistych przejawów zainteresowania Nowikowa problematyką pedagogiczną, stało się miejscem, w którym skrzyżowały się drogi Nowikowa i Nikołaja Karamzina; na jego łamach ukazała się pierwsza oryginalna opowieść Karamzina, Eugeniusz i Julia (1789). Określenie „okres karamzinowski”

2 Tamże.

3 В. О. Ключевский, Новиков и коренные, исторически сложившиеся причины, обусловивиие его деятельность, [w:] В. И. Покровский, Николай Иванович Новиков: его жизнь и сочинения. Сборник историко-литературных статей, Москва 2010, s. 199.

4 Zob. A. И. Кондратьев, Новиковские издания, [w:] Книга в России, ч. 1. Русская книга от начала письменности до 1800 года, ред. В. Я. Адарюков, А. А. Сидоров, Москва 2008, s. 287357.

5 В. Семенников, Книгоиздательская деятельность Н. И. Новикова и Типографической компании, Петербург 1921. Por. tenże, Раннее издательское общество Н. И. Новикова (1773 года). Оттиск из журнала „Русский библиофил”, Санкт-Петербург 1912; tenże, Собрание старающееся о переводе иностранных книг, учрежденное Екатериной II. 1768-1783 г2. Историко-литературное исследование, Санкт-Петербург 1913. 
- stosowane dotąd raczej w odniesieniu do dziejów literatury niż do szeroko rozumianego rozwoju rynku wydawniczego („czy był w historii literatury rosyjskiej okres karamzinowski?" - pytał Grigorij Makogonienko, udzielając odpowiedzi twierdzącej ${ }^{6}$ ) - może odnosić się do lat 1789-1803 (jeżeli na plan pierwszy wysuwać działalność samego Karamzina) lub do lat 1789-1812 (przy uwzględnieniu działalności jego naśladowców), bądź nawet, zgodnie z sugestią Makogonienki, do całego drugiego dziesięciolecia XIX stulecia ${ }^{7}$. Warto pamiętać, że lata trzydzieste XIX wieku zapiszą się w dziejach kultury rosyjskiej jako „okres smirdinowski”, związany z działalnością wydawcy i księgarza Aleksandra Smirdina, pierwszego, który wprowadził spójny system honorariów autorskich, zwiększył na nieznaną dotąd skalę nakłady książek przy jednoczesnym obniżeniu ich cen w sprzedaży detalicznej ${ }^{9}$.

Oto w jaki sposób podsumował znaczenie działalności Nowikowa, Karamzina i Smirdina Fadiej Bułharyn na łamach wydawanej przez siebie gazety „Северная пчела" w 1833 roku:

Nowikow w ciągu swojego życia podwoił skarbnicę naszego [tj. rosyjskiego - M. D.] piśmiennictwa i o cały wiek popchnął do przodu oświecenie ${ }^{10}$.

Karamzin [...] pozostawił po sobie całą szkołę, [...] uważającą go za swojego prekursora. Nowikow zaś był pierwszym i ostatnim w swoim rodzaju ${ }^{11}$.

Smirdin nie jest oczywiście Nowikowem. Jest on tylko księgarzem, ale księgarzem niezwykłym, powodowanym gorącą miłością do $[\ldots]$ Rosji ${ }^{12}$.

Przedmiotem rozpatrzenia staną się w niniejszej pracy inicjatywy wydawnicze z okresów „nowikowowskiego” i „karamzinowskiego” związane z szeroko rozumianą sferą wychowania i kształcenia. Ich przegląd dopełni omówienie wystąpień teoretycznych na temat wychowania oraz wybranych kart z dziejów instytucji oświatowych, ograniczonych, rzecz oczywista, do tych, które w jakiś sposób łączą się z rozpatrywanymi przedsięwzięciami wydawniczymi.

Wspomniana rozprawa O wychowaniu i nauczaniu dzieci stanowi najważniejszą pracę teoretyczną Nowikowa z dziedziny pedagogiki. „Wychowanie dzieci zarówno dla państwa, jak i dla [...] rodziny jest nadzwyczaj ważne" - zaznacza Nowikow na wstępie, dodając, że „rozkwit państwa, pomyślność narodu zależą nieodłącznie od czystości obyczajów, a czystość obyczajów [...]

6 Г. Макогоненко, Был ли карамзинский период в истории русской литературы?, „Русская литература" 1960, № 4, s. 3-32.

7 Tamże.

8 Por.: В. Г. Белинский, Литературные мечтания, [w:] Собрание сочинений в трех томах, т. 1. Статьи и рецензии 1834-1841, ред. М. Я. Полякова, Москва 1948, s. 7-89.

9 Zob. m.in. T. Гриц, В. Тренин, М. Никитин, Словесность и коммерция. Книжная лавка А.Ф. Смирдина, ред. В. Б. Шкловский, Б. М. Эйхенбаум, Москва 2001.

10 Ф. Булгарин, О общеполезном предприятии книгопродавца А Ф. Смирдина, „Северная пчела" 1833, № 299, s. 1184.

11 Tamże.

12 Ф. Булгарин, О общеполезном предприятии книгопродавца А. Ф. Смирдина, „Северная пчела" 1833, № 300, s. 1187. 
od wychowania”13; w nim mają początek „cnota, zamiłowanie do porządku, poczucie wartości”, a także „patriotyzm i szlachetna [...] duma narodowa”"14. Główną część rozprawy zajmują rozważania o trzech rodzajach wychowania, nastawionych na ciało (rozwój sprawności fizycznej) oraz "rozum” i "serce”; zwraca uwagę w niej przejrzystość wykładu, w szczególności w częściach o „rozumie” i „sercu”, pomyślanych jako kilkupunktowe spisy zasad: pierwszą z nich otwiera nakaz rozwijania naturalnej dziecięcej ciekawości świata, w drugiej za najważniejszą uznana zostaje zasada kierowania się dobrem. Całość uzupełniają rozważania o celach i składnikach procesu wychowania, zogniskowane wokół jednej zasady głównej: działania wychowawcze winny prowadzić do stworzenia „szczęśliwego człowieka i pożytecznego obywatela”" ${ }^{15}$. Przy przedstawianiu poszczególnych kwestii Nowikow odwołuje się do myślicieli zachodnioeuropejskich, wśród których szczególne miejsce zajmuje John Lock, wspomniany w przypisie do końcowej - programowej - części wstępu do rozprawy:

[...] smutne obserwacje tego, że wciąż [...] niewłaściwe wykorzystanie czasu, nadmierna skłonność do rozrywek przeszkadzają w wyrobieniu nawyku czytania i wyborze pożytecznych zajęć [...] skłoniły nas do rozpropagowania za pośrednictwem [...] „Wiadomości” tych zasad wychowania, bez których znajomości [...] wszelkie przedsięwzięcia [...] okazują się w większości bezowocne. Będziemy przy tym powoływać się na najlepsze dzieła zagraniczne* i radzi będziemy, jeśli wesprzemy drogę do oświecenia...

* Jedno z najważniejszych dzieł, mianowicie Anglika Locka rozważania o wychowaniu [tj. Myśli o wychowaniu - M. D.], już dawno zostały przetłumaczone na język rosyjski; ale czyż wielu je czyta? ${ }^{16}$

Miejscem publikacji rozprawy $O$ wychowaniu $i$ nauczaniu dzieci stały się „dodatki” do gazety „Московские ведомости”, nazwanej tu skrótowo „Wiadomościami". Na tych samych łamach zostały zamieszczone inne prace pedagogiczne Nowikowa: Rozważania o niektórych sposobach pobudzenia ciekawości w młodych ludziach oraz O wczesnym początku edukacji dzieci, stanowiące rozwinięcie tez zawartych w rozprawie $O$ wychowaniu i nauczaniu dzieci, a także $O$ sokratejskim sposobie nauczania i $O$ wychowaniu estetycznym ${ }^{17}$. Zapowiedziany we wstępie do rozprawy $O$ wychowaniu i nauczaniu dzieci zamiar rozpropagowania w Rosji „zasad wychowania” odnosi się wprawdzie bezpośrednio do zawartości gazety „Московские ведомости”, ale pośrednio również do całej Nowikowowskiej działalności wydawniczej.

Z zestawienia W. Siemiennikowa wynika, że z Nowikowem łączy się wydanie 944 pozycji, spośród których z okresu „petersburskiego” pochodzą 53, z „moskiewskiego" zaś $-875^{18}$. Jak wyliczył L. B. Swietłow, bazujący na bibliografii

13 Н. И. Новиков, О воспитании и наставлении детей, [w:] Антология педагогической мысли России XVIII века, ред. Г. Н. Волков, С. Ф. Егоров, А. Н. Копылов, Москва 1985, s. 289-290.

14 Tamże, s. 290.

15 Tamże, s. 295.

16 Tamże, s. 294.

17 Zob. Антология педагогической мысли..., s. 330-346.

18 В. Семенников, Книгоиздательская деятельность Н. И. Новикова..., s. 9-137. Pozostałych 16 pozycji stanowią wydania nieoficjalne (tamże, s. 138-140). 
Siemiennikowa, miejscem druku większości tytułów - aż 558 - stała się drukarnia Uniwersytetu Moskiewskiego; na drugim miejscu znalazła się pod tym względem drukarnia Kompanii Typograficznej, w której światło dzienne ujrzało 267 z nich, trzecie zajęła drukarnia Łopuchina z 50 tytułami ${ }^{19}$. Z innego wyliczenia Swietłowa wynika, że zagadnień pedagogicznych dotyczy 40 pozycji, stanowiących 4,3\% ogółu produkcji wydawniczej Nowikowa; najliczniejszą grupą okazała się literatura piękna (345 pozycji, czyli 36,6\% ogółu), najmniej liczną - prace z zakresu nauk przyrodniczych i językoznawstwa (po 7 tytułów, czyli po $0,7 \%{ }^{20}$. O ile jednak dokonanie precyzyjnego podziału wydawanych przez Nowikowa pozycji ze względu na miejsce druku nie nastręcza większych trudności, o tyle wyliczenie udziału pozycji „pedagogicznych” w całokształcie Nowikowowskich inicjatyw wydawniczych możliwe jest tylko w przybliżeniu. Co więcej, nie sposób jednoznacznie określić liczebność jakiejkolwiek wyodrębnianej grupy tematycznej: część pozycji wykazuje bowiem przynależność do więcej niż jednej z nich, liczna - obejmująca aż 39 tytułów - jest też grupa „varia” („różności”), mieszcząca pozycje nieprzystające do żadnej z wymienionych wcześniej. Jak zatem zakwalifikować chociażby podręcznik do matematyki, skoro w zestawieniu Swietłowa jest zarówno grupa „podręczniki”, jak i grupa „matematyka”? Co zrobić z dziełami literackimi pisanymi z myślą o wychowaniu młodzieży? Jak potraktować prace o dziejach Rosji, które rzucają światło również na dzieje innych krajów, skoro przez Swietłowa historia powszechna i historia państwa rosyjskiego są wyraźnie rozgraniczane itd.? Przed pokusą „szufladkowania” tematycznego Nowikowowskiej produkcji wydawniczej ${ }^{21}$ przestrzegał Iwan Martynow (również opierający się na zestawieniu W. Siemiennikowa, ale odnoszący się do niego z większym dystansem niż Swietłow, czego świadectwem jest bardziej oględne szacowanie przez niego wielkości produkcji Nowikowa jako przekraczającej 1000 tytułów): „należy pamiętać o swego rodzaju synkretyzmie nauki i literatury XVIII wieku, o wieloaspektowości, skomplikowanej kompozycji [...] i wielorakim przeznaczeniu czytelniczym dzieł zaliczanych do tej czy innej kategorii; dlatego każda próba precyzyjnej systematyzacji całej Nowikowowskiej produkcji według jej tematyki niechybnie rozbije się w związku z niekompletnością naszej wiedzy o tych książkach i różnorodnością ich zawartości”22. Martynow doradza więc porzucenie „dokładnych wyliczeń statystycznych” na rzecz określenia „proporcji między głównymi grupami tematycznymi”, które to proporcje w całokształcie produkcji wydawniczej Nowikowa prezentują się, jego zdaniem, następująco: „pierwsze miejsce [...] zajmuje literatura piękna, oryginalna i przekładowa (około 50\%); na dalszym plasują się dzieła teologiczne i masońskie (około 20\%), jeszcze dalej prace z zakresu nauk społecznych i politycznych [...], pedagogicznych, ekonomicznych..."23. Bez względu na to jednak, czy ograniczymy zainteresowania do rozpraw o tematyce pedagogicznej, czy też rozszerzymy

19 Л. Б. Светлов, Издательская деятельность Н. И. Новикова, Ленинград 1946, s. 60.

20 Tamże, s. 61.

21 Por. np. klasyfikację produkcji wydawniczej Johanna Jacoba Weitbrechta: Г. А. Фафрурин, К истории академической книжной торговли в России в эпоху Екатерины II. Деятельность Иоганна Вейтбрехта в Санкт-Петербурге, Санкт-Петербург 2010, s. 108-205.

22 И. Ф. Мартынов, Книгоиздатель Николай Новиков, Москва 1981, s. 72.

23 Tamże. 
je na dzieła literackie o wymowie wychowawczej oraz podręczniki, słowniki i inne pozycje wspierające proces kształcenia, niezmienny pozostaje fakt, że najwięcej spośród nich ukazało się w „moskiewskim” okresie działalności Nowikowa, zwłaszcza w 1788 roku.

Wśród klasyków europejskiej myśli pedagogicznej, którzy znaleźli się w polu widzenia Nowikowa, ważne miejsce przypadło Janowi Amosowi Komeńskiemu i Johnowi Locke'owi. W tym samym roku - 1788 - ukazały się Świat w obrazach Komeńskiego ${ }^{24}$ oraz traktat $O$ wychowaniu Locke'a ${ }^{25}$, przy czym oba dzieła po raz drugi na gruncie rosyjskim. Komeński i Locke należą do myślicieli, którzy wprowadzili europejską - $w$ tym rosyjską - pedagogikę na nowe tory rozwojowe: pierwszy „wprowadzał do szkoły życie i świat współczesny, wiedzę o przyrodzie i [...] społeczeństwie, naukę myślenia i działania praktycznego"26, drugi przekonał o „możności kształtowania duszy i umysłu dziecka przez jego otoczenie”, umysł człowieka jest bowiem w chwili narodzin „«czystą tablicą», którą dopiero zapełnia doświadczenie"27.

Literatura piękna stanowiła przedmiot szczególnej troski Nowikowa jako wydawcy. W gazecie „Московские ведомости” w 1784 roku utyskiwał on na brak odpowiedniej literatury dla młodego czytelnika, widoczny zresztą nie tylko dla niego, ale także dla samych rodziców:

Rozumni rodzice i wszystkie osoby troszczące się o wychowanie dzieci przyznają, że pośród różnych niedogodności w procesie wychowania jedną z głównych jest w naszym kraju [tj. w Rosji - M. D.] to, że dzieci nie mają co czytać. Muszą czytać takie książki, które albo są dla nich całkowicie niezrozumiałe, albo dostarczają im takich wiadomości, na których otrzymanie jest dla nich zbyt wcześnie. Z tego powodu zamierzamy przeznaczyć Dodatki do „Wiadomości” na lekturę dla dzieci i zamieszczać w nich utwory historyczne, z zakresu historii naturalnej, moralizatorskie i różne inne, które - napisane stylem odpowiednim dla dzieci - stanowiłyby [...] zajęcie pożyteczne i jednocześnie przyjemne ${ }^{28}$.

Sąd ten w niemal niezmienionej postaci Nowikow powtórzy w 1785 roku, w przedmowie programowej do pierwszego numeru czasopisma „Детское чтение для сердца и разума":

Dotychczas w naszym języku ojczystym nie było niczego, co służyłoby wyłącznie jako lektura dla dzieci. Dlaczego dzieci uczące się francuskiego czy niemieckiego mogły cieszyć się czytaniem książek francuskich i niemieckich, te natomiast, które [...] nie znały tych języków, albo niczego nie czytały, albo były zmuszane do czytania rzeczy nieodpowiednich dla siebie... ${ }^{29}$

24 Иоанна Амоса Комения Видимый мир, на латинском, российском, немецком, италианском и фрранцузском языках представленный, или Краткое введение..., изд. 2, Москва 1788.

25 О воспитании детей, г. Локка. Переведено с французского на российский язык Московского университета Профрессором Николаем Поповским. 2 части, Москва 1788.

26 B. Suchodolski, Komeński, Warszawa 1979, s. 15.

27 K. Mrozowska, Wstęp, [w:] J. Locke, Myśli o wychowaniu, przekł. F. Wnorowski, WrocławKraków 1959, s. XXVI.

28 [Б. п.], Объявление о подписке к получению Московских Ведомостей на будущий 1785 год, „Московские ведомости” 1784, № 92, 16 ноября, s. 822.

29 Б. п. [Н. И. Новиков], Благородному российскому юношеству, „Детское чтение для сердца и разума" 1785, ч. 1, s. 1-2. 
Przegląd dzieł literackich, których wydanie - po raz pierwszy czy kolejny - czytelnicy rosyjscy zawdzięczali Nowikowowi, należy poprzedzić uwagą, że walorami wychowawczymi odznacza się większość z nich. Mówimy przecież o czasach Oświecenia, z powszechnym dla nich przekonaniem o instrumentalnym charakterze literatury i jej wyraźnym zorientowaniu dydaktycznym. Bo czyż nie odznacza się nimi powieść Jeana-Françoisa Marmontela Belizariusz (1765), pomyślana jako „traktat dla władców” czy „kodeks moralności władców”, zalecająca im wychodzenie naprzeciw potrzebom różnych grup społecznych, kontrolowanie wysokości podatków, zwalczanie przejawów ludzkiej zachłanności itp., albo druga powieść tegoż pisarza, Inkasy, czyli zagłada państwa Peru (1777), dostarczająca przykłady dobrej i złej „organizacji społeczeństw”, czy wreszcie Marmontelowskie powiastki moralizatorskie, powstałe „dla pouczenia czytelników, w atrakcyjnej formie, na sposób lekki i żartobliwy"30. Belizariusz został wydany przez Nowikowa w roku 1785, Inkasy, czyli zagłada państwa Peru - w 1782, zbiór powiastek moralizatorskich - w $1787^{31}$. Powieść o Belizariuszu oraz powiastki moralizatorskie ukazywały się przy tym po raz kolejny. Zainteresowanie prozą Marmontela stanowi kolejny punkt styczny między Nowikowem i Karamzinem, spod pióra którego wyszedł przekład drugiej serii powiastek pisarza francuskiego, wydany w latach 1794-179832. Wśród utworów literackich przeznaczonych dla młodego czytelnika (bądź adaptowanych na jego potrzeby, co stanowiło w czasach Oświecenia częstą praktykę) wysuwają się na plan pierwszy Podróże Guliwera (1726) Jonathana Swifta, których część III Nowikow wydał w Petersburgu w 1773 roku i których części I-IV wydał - już w Moskwie - w 1780 roku (w obu przypadkach tłumaczem był Jerofiej Korżawin) $)^{33}$, oraz opublikowane w 1781 roku Przypadki Robinsona Crusoe (1719) Daniela Defoe, a właściwie jedna z ich przeróbek ${ }^{34}$, nosząca charakterystyczny - również typowy dla czasów Oświecenia - tytuł Nowy Robinson

30 E. Rzadkowska, Francuskie wzorce polskich Oświeconych. Studium o recepcji J. F. Marmontela w XVIII w., Warszawa 1989, s. 69, 97-98, 108.

31 Инки, или разрушение Перуанской Империи. Соч. Мармонтеля. Пер. с франц. Марья Сушкова. 2 части, Москва 1782; Велизар, сочинение Господина Мармонтеля, члена Французской Академии, переведен на Волге, Москва 1785; Нравоучительные сказки г. Мармонтеля, члена Французской Академии. 3 части. Издание второе. Пер. Павел фон Визин, Москва 1787. Zob.: M. Dąbrowska, Jean-François Marmontel i rosyjska proza sentymentalna drugiej połowy XVIII wieku, „Przegląd Rusycystyczny” 2005, nr 4, s. 21-34.

32 Новые Мармонтелевы повести, изданные Н. Карамзиным. Перевод с французского, ч. 1-2, Москва 1794-1798. Własne tłumaczenia powiastek zamieścił Karamzin także w wydawanych przez siebie czasopismach „Московский журнал” і „Вестник Европы”. Zob. О. Б. Кафанова, Н. М. Карамзин - переводчик Мармонтеля, [w:] Проблемы метода и жанра, вып. 6, Томск 1979, s. $157-176$.

33 Путешествий Гулливеровых книга третия... перевед. Ерофреем Коржавиным, Санкт-Петербург 1773; Путешествий Гулливеровых книга 1[-4]. Перевед. Ерофеем Коржавиным, 2-е изд., [Москва] 1780. Zob. Ю. Д. Левин, Свифот Джонатан, [w:] Русско-европейские литературные связи XVIII века. Энциклопедический словарь. Статьи, ред. П. Е. Бухаркин, Санкт-Петербург 2008, s. 195-197; Ю. Д. Левин, Раннее восприятие творчества Джонатана Свифтma, [w:] tenże, Восприятие английской литературы в России. Исследования и материалы, Ленинград 1990, s. 103-133.

34 Najbardziej znana wyszła spod pióra Joachima Heinricha Campego w 1780 roku. 
Crusoe... ${ }^{35}$. O sukcesie obu książek zadecydowała atrakcyjna fabuła, elementy baśniowe oraz, co akurat mogło zostać dostrzeżone raczej przez dojrzałego niż młodego czytelnika, pewien uniwersalizm wymowy moralnej i filozoficznej; należy pamiętać oprócz tego, że Przypadkom Robinsona Crusoe utorowała drogę do młodego odbiorcy pochlebna opinia Jeana-Jacquesa Rousseau, który w powieści-traktacie pedagogicznym Emil, czyli o Wychowaniu (1762) napisał: „[...] ponieważ nie możemy obyć się bez książek, przeto jest jedna, która stanowi [...] najudatniejszą rozprawę o wychowaniu naturalnym; książka ta będzie pierwszą, którą mój Emil przeczyta: [...] to Robinson Crusoe"36. W kontekście Przypadków Robinsona Crusoe należy wspomnieć o opublikowanej w czasopiśmie „Детское чтение для сердца и разума” w 1786 roku Pamiętnej opowieści o pewnym Szkocie, mieszkającym kilka lat na bezludnej wyspie ${ }^{37}$, przypominającej szkockiego żeglarza Alexandra Selkirka (Selcraiga), którego losy - czteroletni pobyt na bezludnej wyspie - stały się inspiracją przy tworzeniu postaci Robinsona. Powieści o Robinsonie i Guliwerze znalazły się w kanonie lektur młodego Europejczyka.

Obecność w kręgu zainteresowań wydawniczych Nowikowa podręczników, słowników i innych pozycji wspierających proces dydaktyczny wiąże się w naturalny sposób z przejęciem przez niego drukarni uniwersyteckiej. Zarys podstaw składni niemieckiej do wykorzystania na wykładach publicznych w Imperatorskim Uniwersytecie Moskiewskim (1780) I. G. Szwarca - oto jedna z publikacji, która związek z Uniwersytetem Moskiewskim ma „zapisany” w tytule. I dwa inne przykłady, dodatkowo rzucające światło na strukturę organizacyjną uczelni: Nowy leksykon w językach niemieckim, francuskim, łacińskim, włoskim i rosyjskim, wydany przez Matwieja Gawriłowa, członka Seminarium Pedagogicznego założonego przy Imperatorskim Uniwersytecie Moskiewskim oraz Podstawy prawa wekslowego do wykorzystania na Wydziale Prawnym Uniwersytetu Moskiewskiego (oba tytuły z 1781 roku). Duża część wydawanych przez Nowikowa podręczników wyszła spod pióra Dmitrija Aniczkowa, wykładowcy logiki, matematyki i filozofii; zajmował się on ponadto łłumaczeniem podręczników zagranicznych i opracowaniem wypisów tekstów naukowych. Oprócz prac z zakresu nauk matematycznych (algebra, geometria, trygonometria itp.) w spisie Nowikowowskiej produkcji wydawniczej znajdują się prace z zakresu geografii, historii, poetyki, retoryki, gramatyki języka rosyjskiego oraz języków obcych (starożytnych i nowożytnych), wydawnictwa typu encyklopedycznego; całkiem liczną grupę stanowią publikacje edukacyjne dla najmłodszych, w tym elementarze ${ }^{38}$.

35 Новый Робинзон Крузе, или Похождения славного Аглинского мореходиа. Перевод с немецкого, Москва 1781. Zob. Ю. Д. Левин, Дефо Даниэль, [w:] Русско-европейские литературные связи..., s. 75-76; М. П. Алексеев, „Робинзон Крузо” в русских переводах, [w:] Международные связи русской литературы. Сборник статей, ред. М. П. Алексеев, Москва-Ленинград 1963, s. 86-100.

36 J.-J. Rousseau, Emil, czyli O wychowaniu, przeł. W. Husarski, t. 1, Wrocław 1955, s. 225.

37 [Б. п.], Достопамятная повесть о некотором Шотландце, жившем несколько лет на пустом острове, „Детское чтение для сердца и разума” 1786, ч. 7, s. 116-121.

38 Por. wykazy asortymentu księgarskiego, np. : [Б. п.], [В Университетской книжной лавке, 
Po kilka wydań miały na przełomie XVIII i XIX stulecia nie tylko książki, ale także czasopisma. Aż trzech doczekało się „Детское чтение для сердца и разума", jak wiadomo, po raz pierwszy wydane w latach 1785-789 (w dwudziestu częściach, po cztery w każdym roku): drugie wydanie wychodziło w latach 1799-1804, trzecie zaś (chociaż oznaczone jako drugie, z Moskwą i Orłem jako miejscem publikacji) pochodzi z 1819 roku ${ }^{39}$. Pod kierunkiem Nowikowa wychodziło ono tylko przez pierwsze dwa lata. Później na plan pierwszy wysunęli się w pracach nad nim Nikołaj Karamzin i Aleksander Pietrow; w ostatnim roku - w związku z wyjazdem Karamzina za granicę - całość przygotowań spoczęła na Pietrowie ${ }^{40}$. Właśnie zgrupowanie osób żywo zainteresowanych problematyką pedagogiczną należy do głównych zasług Nowikowa jako założyciela czasopisma „Детское чтение для сердца и разума"41.

Program czasopisma „Детское чтение для сердца и разума” Nikołaj Nowikow wyłożył w skierowanej do „szlachetnej rosyjskiej młodzieży” przedmowie do numeru pierwszego, rozpoczynając ją od wyjaśnienia powodów jego wydawania i zapowiadając zawartość ${ }^{42}$. Jak wiadomo, u podstaw założenia pisma legł zamiar zapełnienia luki na rosyjskim rynku wydawniczym, niechętnym dotąd młodemu czytelnikowi. Podsunięte lektury miały za zadanie, z jednej strony, kształtować sferę emocjonalną i moralną, z drugiej wzbogacać rozum wiedzą z różnych dziedzin; zgodnie z hasłami Oświecenia, lektura miała być jednocześnie „przyjemna” i „pożyteczna”. W przedmowie daje o sobie znać rys postawy, który określi ton całego pisma, a mianowicie „przyjacielskie i zarazem poważne podejście do dziecięcych czytelników"43.

Najważniejszym wyróżnikiem pisma „Детское чтение для сердца и разума” miała stać się zapowiadana przez Nowikowa w przedmowie i odnotowana przez Karamzina w artykule O sprzedaży książek i miłości do czytania w Rosji różno-

состоящей у нового каменного Никольского мосту, в доме под № 144, продаются следующие книги...], „Прибавление к Московским Ведомостям” 1784, № 101, 18 декабря, s. nlb.

39 Ostatnie wydanie nie stanowiło przy tym mechanicznego powtórzenia wydania pierwszego. Różnice między nimi dotyczą trzech kwestii: numeracji stron i kolejności następowania po sobie poszczególnych tekstów, a także mott biblijnych do początkowych pięciu części pisma (Prz 1,7; Mt 5,11; Mt 5,42; Mt 6,13; Mt 7,1-2), obecnych w wydaniu pierwszym i pominiętych w trzecim.

40 Zmiana redaktorów pociągnęła za sobą zmiany w strukturze pisma. O ile jego założyciel wyraźnie preferował wypełnianie poszczególnych części dużą liczbą tekstów, skromnych objętościowo i różnorodnych pod względem gatunkowym, o tyle jego kontynuatorzy stawiali na pozycje obszerniejsze, których, siłą rzeczy, mieściło się w danej części znacznie mniej: dla przykładu, w części l (z 1785 roku) znalazło się ponad trzydzieści utworów, gdy tymczasem w częściach IX-XII z 1787 roku było ich po kilka. Różnorodność powróciła do pisma w częściach XV-XVI (z 1788 roku). Odmienności w kompozycji początkowych i późniejszych części skłoniły N. A. Biekietową do sformułowania następującego wniosku: „czasopismo rozpada się na dwie połowy, których nie da się rozpatrywać razem, są one bowiem tak różne, że sprawiają wrażenie dwóch różnych pism" (zob. Н. А. Бекетова, Очерк русской детской журналистики, [w:] Материалы по истории русской детской литературы (1750-1855), ред.

А. К. Покровская и Н. В. Чехов, вып. 1, Москва 1927, s. 93.

41 Por. Н. В. Чехов, Очерки истории русской детской литературы (1750-1855), [w:] Материалы по истории..., s. 35.

42 Б. п. [Н. И. Новиков], Благородному российскому..., s. 3-8.

43 Н. А. Бекетова, Очерк русской детской..., s. 93. 
rodność zamieszczanych tekstów, zarówno formalna, jak i tematyczna. Na jego zawartość składają się bajki, zagadki i sentencje, powiastki i opowieści, często - w całości lub we fragmentach - przybierające postać listów, zestawień pytań i odpowiedzi czy zapisów rozmów. Zróżnicowanie treściowe przejawia się na dwa sposoby, również zasygnalizowane w przedmowie: „utwory moralizatorskie” miały sąsiadować w nim z „pracami z zakresu fizyki, historii naturalnej, geografii i pewnych innych nauk, których [...] znajomość jest potrzebna"44. Przykładem części, w której przeważają pozycje z drugiej grupy, jest część piąta, wypełniona materiałami o świecie przyrody: ziemi, słońcu, księżycu, wodzie, górach, zaćmieniach słońca i trzęsieniach ziemi, zwierzętach itp. Teksty o wymowie moralizatorskiej, pozwalające odtworzyć Nowikowowski system wartości, zdominowały cztery początkowe części pisma. Przy propagowaniu poszczególnych „cnót”, wśród których naczelne miejsce zajęły przestrzeganie zasad religijnych, przywiązanie do rodziców, wierność w przyjaźni, umiar i silna wola, wydawca rzadko posługuje się formą traktatu teoretycznego, sięgając w tym celu po łatwo przemawiające do „serca i rozumu” przykłady. Tym rzadkim przypadkiem jest mowa do „miłych czytelników” O naśladowaniu rodziców, zawierająca następujący - wyraziście sformułowany w zakończeniu - przekaz:

Wasze własne uczucia i dobre wychowanie [...] szybko pokażą wam, co w waszych rodzicach jest warte naśladowania i co jest jego niewarte ${ }^{45}$.

Zdaniem Nowikowa, naśladowanie rodziców jest naturalnym zachowaniem młodego człowieka, a miłość do nich stanowi dziecięcą powinność, nie zwalnia to wszakże młodych ludzi ze zdroworozsądkowego spojrzenia na rodziców i odstąpienia od powielania ich złych cech i zachowań ${ }^{46}$. Nawet tu jednak - aby wzmocnić siłę przekazu - pojawiają się przykłady:

Być może ktoś z was ma porywczego ojca, który za każde przewinienie gniewa się, krzyczy i wymyśla. Zapytajcie sami siebie, czy dobrze jest [...] go naśladować? ${ }^{47}$

Wzmocnić siłę oddziaływania wychowawczego mają też argumenty natury religijnej:

Krótko mówiąc, przedkładajcie ponad wszystko przykazania boże i swoje własne sumienie ${ }^{48}$.

44 Б. п. [Н. И. Новиков], Благородному российскому..., s. 5.

45 [Б. п.], О подражании родителям, „Детское чтение для сердца и разума” 1785, ч. 3 , s. $17-18$.

${ }^{46}$ Por.: „Mając na uwadze to, jak wielki jest wpływ towarzystwa i jak skłonni jesteśmy wszyscy, a szczególnie dzieci, do naśladownictwa, pozwolę sobie zwrócić uwagę rodziców na jedną rzecz, a mianowicie na to, że ten, kto chce, aby jego syn miał szacunek dla niego i dla jego rozkazów, musi sam odnosić się z wielkim poważaniem do swego syna. [...] Nie powinniście robić przy nim nic takiego, czego nie chcecie, aby naśladował. Jeśli zdarzy się wam przypadkowo popełnić coś, co jemu poczytalibyście za błąd, to z pewnością zasłoni się on waszym błędem..." (L. Locke, Myśli..., s. 61-62). O ile w czasopiśmie rosyjskim problem złego przykładu, który dają rodzice, zostaje przedstawiony z perspektywy dzieci, o tyle w rozprawie Locke'a pokazany jest on od strony rodziców.

47 [Б. п.], О подражании..., s. 16-17.

48 Tamże, s. 19. 
Nie tylko nie przeczy wymowie tego traktatu, ale pod pewnymi względami podkreśla ją Rozmowa o posłuszeństwie, w jakim dzieci powinny pozostawać względem rodziców, oparta na schemacie rozmowy dorosłych z grupą dzieci: by przekonać czytelników do posłuszeństwa rodzicom, przedstawiona zostaje najpierw historia chłopca, który samowolnie wsiadł na łódkę i byłby - po wypadnięciu z niej do wody - utonął, gdyby nie pomoc służącego, następnie zaś opowiadanie o Dobronrawie i Złomyśle (nadawanie postaciom imion znaczących stanowi w czasach Oświecenia stałą praktykę) $)^{49}$. Umiaru uczą opowieści: Wstrzemięźliwość, pomyślana jako zapis rozmowy ojca z synem ${ }^{50}$, oraz Umiarkowanie i nieumiarkowanie, rozpoczynająca się od wykładu teoretycznego, a w części właściwej wypełniona przykładami postępowania według obu zasad $^{51}$. Oto treść pierwszej z nich: na pytanie syna, co to jest wstrzemięźliwość, ojciec opowiada dzieje chłopca karmionego przez nianię samymi słodyczami; pozbawiony ich, zaczął dla zdobycia na nie pieniędzy kraść i aby uniknąć kary, schował się na statku i zginął na nim w czasie katastrofy morskiej; nauka przyniosła pożądany skutek: syn, wcześniej płaczem domagający się spełnienia zachcianek, zmienił się. Potrzebę rozróżniania przyjaciół prawdziwych i fałszywych sygnalizuje opowieść Przyjaźń, oparta na często stosowanym w literaturze oświeceniowej motywie wędrówki dla zdobycia mądrości życiowejej. Siły woli uczy opowieść Tylko początek jest trudny, przedstawiająca historię małego Fiodora, który nie lubił porannych pobudek do chwili, gdy przekonał się, jakie dają one korzyści (dobry humor, większa chęć do nauki itd.) ${ }^{53}$. Na wyrazistych przykładach opiera się szereg innych utworów: Najlepszy podarunek, wpajający przekonanie o własnej wartości, czy Dwaj robotnicy, uczący rozumnych wyborów życiowych ${ }^{54}$. Na osobne odnotowanie zasługuje opowieść Obraz życia ludzkiego, porównująca życie do łąki, raz ocienionej, raz rozświetlonej promieniami słońca:

Życie nasze podobne jest do [...] łąki. Gdy jesteśmy pobożni i cnotliwi, [...] żyjemy w pomyślności, niczym oświetleni promieniami słonecznymi. Jednak pomyślność ta nie trwa nieprzerwanie. Nagle napływa na nas obłok nieszczęścia i nieoczekiwanie pokrywa nas cień... ${ }^{55}$

Ograniczenie czy wręcz porzucenie tonu mentorskiego, suchego i beznamiętnego, na rzecz barwnego materiału egzemplifikacyjnego jako doskonalszej metody oddziaływania wychowawczego pozostaje w zgodzie z wytycznymi czołowych europejskich pedagogów; „ze wszystkich [...] sposobów, których należy

49 [Б. п.], Разговор о повиновении, какое дети должны оказывать своим родителям, „Детское чтение для сердца и разума" 1785, ч. 4, s. 88-114.

50 [Б. п.], Воздержность, „Детское чтение для сердца и разума” 1785, ч. 1, s. 224-229.

51 [Б. п.], Умеренность и неумеренность, „Детское чтение для сердца и разума” 1785, ч. 2, s. $51-53$.

52 [Б. п.], Дружба, „Детское чтение для сердца и разума” 1785, ч. 3, s. 3-9.

53 [Б. п.], Начало только трудно, „Детское чтение для сердца и разума” 1785, ч. 2, s. 88-90.

54 [Б. п.], Самой лучший подарок, „Детское чтение для сердца и разума” 1785, ч. 2, s. 216;

[Б. п.], Два работника, „Детское чтение для сердца и разума” 1785, ч. 2, s. 217-218.

55 [Б. п.], Образ человеческой жизни, „Детское чтение для сердца и разума” 1785, ч. 2, s. 72. 
używać przy pouczaniu dzieci i kształtowaniu ich obyczajów, najprostszym [...] i najskuteczniejszym jest stawianie im przed oczy przykładów tego, co chcecie, by czyniły lub unikały" - pisał Locke w Myślach o wychowaniu ${ }^{56}$, a jest to tylko przykład, bo podobne poglądy głosił chociażby Rousseau w Emilu, czyli o wychowaniu.

Dla Karamzina czasopismo „Детское чтение для сердца и разума” stało się miejscem zamieszczenia własnych prób pisarskich: przeważały wśród nich przekłady, w tym powiastek Stéphanie Félicité de Genlis, wychowawczyni dzieci księcia Ludwika Filipa Orleańskiego, moralistki surowszej od Marmontela, oraz utworów Christiana Felixa Weissego, wydawcy poczytnego czasopisma „Der Kinderfreud"57, ale znalazła się także, jak wiadomo, oryginalna opowieść Eugeniusz i Julia ${ }^{58}$. Podobnie można przedstawić ostatnie czasopismo Karamzina - „Вестник Европы", w którym wydawca zamieścił tłumaczenia (w tym utworów Genlis) ${ }^{59}$, ale i swojego Rycerza naszych czasów, pomyślanego jako opowieść o wczesnych etapach życia człowieka ${ }^{60}$. Współpraca z pismem „Детское чтение для сердца и разума" stała się jednym z ostatnich ogniw drogi twórczej Karamzina przed jego podróżą zagraniczną w latach 1789-1790. Po powrocie do kraju jego zainteresowanie problematyką pedagogiczną nie zanikło (na Zachodzie zetknął się przecież z instytucjami oświatowymi, do których należała szkoła dla dziewcząt w Zurychu, opisana przez niego w Listach podróżnika rosyjskiego, publikowanych we fragmentach w piśmie „Московский журнал” w latach 1791-1792), choć w założonym w 1802 roku periodyku „Вестник Европы” zajęła ona miejsce dalekie od pierwszoplanowego.

Właśnie publikacje na temat instytucji oświatowych - różnego szczebla i typu, zarówno w państwie rosyjskim, jak i za granicą - zwracają szczególną uwagę w czasopiśmie „Вестник Европы” w „karamzinowskim” okresie jego wydawania ${ }^{61}$. Na realia rosyjskie rzuca światło zamieszczona w nim w 1803 roku Mowa... radcy kolegialnego Karazina...62, wygłoszona w związku z uzyskaniem zgody na utworzenie w Charkowie uniwersytetu i skierowana do miejscowych ziemian. Uniwersytet Charkowski zaczął działalność na mocy ukazu carskiego z 29 stycznia 1804 roku, zawdzięczając powstanie właśnie Wasilijowi Karazinowi, znanemu matematykowi i działaczowi oświatowemu, oraz zamożnym mieszkańcom miasta,

\footnotetext{
56 J. Locke, Myśli..., s. 73.

57 Zob. О. Б. Кафранова, Библиография переводов Н. М. Карамзина (1783-1800 ге.), „XVIII век”, сб. 16, ред. А. М. Панченко, Ленинград 1989, s. 319-337.

58 Н. М. Карамзин, Евгений и Юлия. Русская истинная повесть, „Детское чтение для сердца и разума" 1789, ч. 18, s. 177-191.

59 О. Б. Кафанова, Библиография переводов Н. М. Карамзина в „Вестнике Европы” (18021803 ге.), „XVIII век”, сб. 17, ред. А. М. Панченко, Санкт-Петербург 1991, s. 249-283.

60 [Н. М. Карамзин], Рыцарь нашего времени, „Вестник Европы” 1802, ч. 4, № 13 (июль), s. 35-51; ч. 5, № 18 (сентябрь), s. 111-125; 1803, ч. 10, № 14 (июль), s. 121-142.

61 Z Karamzinem pismo było związane w latach 1802-1803. W następnych latach kierowaniem zajmowali się Pankratij Sumarokow, Wasilij Żukowski, Władimir Izmajłow i Michaił Kaczenowski. Rezygnacja Karamzina wiązała się z przystąpieniem przez niego do prac nad Historią państwa rosyjskiego.

62 Речь, говоренная в собрании Харьковского Дворянства Депутатом его, Коллежским Советником Карамзиным, испросившим Высочайшее соизволение на основание в городе Харькове Университета, „Вестник Европы” 1803, ч. 10, № 16 (август), s. 235-243.
} 
którzy za jego namową wyłożyli na ten cel znaczące kwoty ${ }^{63}$. Dla porównania warto przypomnieć, że Uniwersytet Moskiewski został utworzony w 1755 roku przez carycę Elżbietę Pietrowną dzięki pomysłowi Michaiła Łomonosowa i staraniom Iwana Szuwałowa ${ }^{64}$. W swojej mowie Karazin roztoczył przed słuchaczami wizje nowej - wspanialszej niż dotychczas - guberni charkowskiej (a pośrednio całej Ukrainy): po założeniu uniwersytetu jej wyróżnikiem będą już nie tylko przyjazny klimat i żyzna ziemia, ale i zastępy wykształconych ludzi - lekarzy, nauczycieli, naukowców; Ukraina stanie się „ośrodkiem oświecenia”, promieniującym na całe Imperium Rosyjskie i nawet Europę, podobnie jak niegdyś Ateny promieniowały przykładem na całą Grecję, a nawet Helladę ${ }^{65}$. Pośrednio mowa wyraża pochwałę władcy, bez zgody którego założenie uniwersytetu nie byłoby możliwe. Z myślą o pochwale cara rosyjskiego powstawała zresztą większość tekstów poświęconych rodzimym instytucjom oświatowym ${ }^{66}$, jak - dla przykładu - „list z $\mathrm{T}^{* * * ”} \mathrm{O}$ nowych szlachetnych szkołach zakładanych w Rosji:

Ledwie tylko ALEKSANDER I wyraził życzenie [...] rozwijać oświecenie w Rosji [...], już we wszystkich głównych miastach [...] powstają [...] szkoły ${ }^{67}$,

chociaż niewolne są od niej również - to znowu przykłady - relacja z otwarcia szkoły dla cudzoziemców w Moskwie (O szkole, założonej dla cudzoziemców w Moskwie przy nowym kościele luterańskim ${ }^{68}$ czy opis uniwersytetu w niemieckiej Getyndze, przesłany do redakcji przez jednego ze studiujących na nim młodych Rosjan ${ }^{69}$ (O Uniwersytecie w Getyndze...). $)^{70}$. Druga z publikacji, odznaczająca się niewątpliwymi walorami poznawczymi, rzuca światło na topografię Getyngi i jej dzieje, najważniejsze wydarzenia z historii uniwersytetu oraz jego stan obecny (struktura, skład profesorski, statut; funkcjonowanie biblioteki, obserwatorium astronomicznego, ogrodu botanicznego itp.). Oddzielną grupę stanowią w piśmie „Вестник Европы” teksty o Uniwersytecie Moskiewskim: jeden z nich dotyczy organizowanych przez niego wykładów otwartych z historii, przyrodoznawstwa, fizyki doświadczalnej i ekonomii, którym „w [...] ciszy i z uwagą" przysłuchują się „...damy, szlachetnie urodzeni młodzieńcy, duchowni, kupcy...”

63 Zob. m.in. «Я смело могу стать пред судом потомков...» (Карамзинский сборник). Посвящается 200-летию Харьковского национального университета им. В. Н. Карамзина, ред. Е. Узбек, Харьков 2004.

64 Zob. А. Ю. Андреев, Организация Московского университета, [w:] tenże, Российские университеты XVIII-первой половины XIX века в контексте университетской истории Европы, Москва 2009, s. 249-285.

65 Речь, говоренная в собрании..., s. 241.

66 Por. J. T. Flynn, The University Reform of Tsar Alexander I 1802--1835, Washington 1988.

67 N. N., О новых благородных училищах, заводимых в России. Письмо из $T^{* * *}$, „Вестник Европы" 1803, ч. 2, № 8 (апрель), s. 358.

68 [Гейдеке], О школе, учрежденной для иностранщев в Москве при Новой Лютеранской церкви, „Вестник Европы” 1803, ч. 12, № 21-22 (ноябрь), s. 54-58.

69 Por. А. Ю. Андреев, Вериина „модернизации”: Геттинген, [w:] Российские университеmы..., s. 233-249.

70 [В. И. Фрейганг], О Геттингенском Университете. (Сочинение одного из молодых Россиян, которые ныне там учатся), „Вестник Европы” 1803, ч. 12, № 23-24 (декабрь), s. 166-207. 
(O publicznym wykładaniu nauk w Uniwersytecie Moskiewskim) ${ }^{71}$, inny ma za temat kształcenie nauczycieli, szczególnie potrzebnych w warunkach rozbudowywania sieci szkolnej (O najlepszym sposobie posiadania w Rosji odpowiedniej liczby nauczycieli) $)^{72}$.

Z perspektywy czasu przedsięwzięcia wydawnicze Nowikowa i Karamzina - zarówno w zakresie produkcji książkowej, jak i czasopiśmiennictwa - jawią się jako jedne z czołowych wydarzeń kulturalnych w Rosji przełomu XVIII i XIX wieku. Studia nad nimi mogą być prowadzone z dwóch perspektyw: po pierwsze, są one samodzielnym przedmiotem badań bibliologicznych i prasoznawczych, po drugie, stanowią źródło do studiów z różnych dziedzin wiedzy, w tym z zakresu nauk pedagogicznych. Innymi słowy, świadczą one o ilościowym i jakościowym rozwoju produkcji wydawniczej w Rosji tych czasów oraz odzwierciedlają proces rozpowszechniania się w tym kraju zachodnioeuropejskiej myśli pedagogicznej i kształtowania się koncepcji rodzimych, powstawanie literatury dziecięcej, wreszcie rozwój instytucji oświatowych. Działalność Nikołaja Nowikowa i Nikołaja Karamzina znalazły uznanie ludzi ich czasów. „Przed Nowikowem mało było książek do czytania dla wszystkich, były one rzadkością" - wspominał po latach Michaił Dmitrijew i dodawał, że za jego sprawą Przypadki Robinsona Crusoe znalazły się „w każdej wiejskiej bibliotece”, a „Детское чтение для сердца и разума” - czasopismo wydawane z udziałem Karamzina - stanowiło „bodaj czy nie najlepsze [...] ze wszystkiego, co zostało wydane w Rosji dla dzieci”73.

71 [Н. М. Карамзин], О публичном преподавании Наук в Московском университете, „Вестник Европы” 1803, ч. 12, № 23-24 (декабрь), s. 261-268 (cytaty ze s. 263-264).

72 Ц. Ц. [Н. М. Карамзин], О верном способе иметь в России довольно учителей, „Вестник Европы” 1803, ч. 8, № 8 (апрель), s. 317-326.

73 М. А. Дмитриев, Мелочи из запаса моей памяти, [w:] tenże, Московские элегии. Стихотворения. Мелочи из запаса моей памяти, Москва 1985, s. 173, 176, 178. 